\title{
A Study on the Effects of Super-Supermarket Service Quality on Satisfaction in Store Selection
}

\author{
Gyeong-Cho Kim*
}

\section{Abstract}

Purpose - Currently, the distribution environment has been changing rapidly because of the advent of super-supermarkets (SSM), which adopt the "price break" and "lowest price" strategies. Specifically, a diversification of the distribution environment allowed customers to reasonably decide where to shop. With a broadened range of criteria governing the choice of a store, determining changes in the distribution environment should be based on customer satisfaction surrounding the service levels of SSMs. This study examines the effects of service quality and product quality of SSMs on customer satisfaction levels, and analyzes whether these factors affect customers' revisit intention directly.

Research design and methodology - A survey method was used and 127 SSM customers responded to the questionnaires that were developed to measure service quality, product quality, customer satisfaction, and store revisit intention. A multi-regression analysis was used to test the hypotheses.

Results - Except hypothesis 2, the other seven hypotheses were supported. Hypothesis 2 suggested a positive relationship between product factors and customer satisfaction.

Conclusions - This study found a systematic effect of service factors and product factors on customer satisfaction and word-of-mouth, and consequently on store revisit intention.

Keywords: Super-Supermarket, Customer Satisfaction, Service Level, Revisit Intention.

JEL Classifications: L81, M31.

\section{Introduction}

\subsection{Background of study}

Currently, domestic super-supermarkets (SSM) have been facing many difficulties due to the recent changes in Distribution

* Assistant Professor, Department of Business Administration, Chodang University, Muan-ro 380, Muan-eup, Muan-gun, Jeonnam, 534-701, Korea. Tel.: 82-61-450-1011. Email: kjkim@chodang.ac.kr.
Industry Development Act. According to the newly revised act, it becomes impossible for large-scale discount stores over $300 \mathrm{~m}^{2}$ and SSM to launch new stores near traditional markets, especially within a radius of $500 \mathrm{~m}$. Local government heads now can designate these areas as traditional business preserve area and prohibit SSM launching. In addition, Coexisting Act (a law to promote coexistence and cooperation between major conglomerates and small and medium-sized businesses) will also hit large-scale discount stores, once it is passed. The purpose of Distribution Industry Development Act, when it was legislated, was to protect small business owners from SSM's threats. In fact, domestic distribution industry has been influenced a lot by large-scale discount stores with "price break".

However, large-scale discount store market is now saturated following rapid expansion, and the growth rate becomes slower due to fierce competition. The optimal number of large-scale discount stores is $200-250$ for per 0.2 million population. It is already in super-saturation stage. On one hand, large-scale discount stores tend to keep expansion to dominate the market, and on the other hand, they seek diversified changes to overcome growth limits. Especially, private brand (PB) sale is one of the main strategies of large-scale discount stores. In addition, a new concept of discount store which applies super-store to existing large-scale discount stores newly arises, and overseas expansion along with business field switch is increasing. In Seoul and the metropolitan area, large-scale discount store market is already saturated so that the competition among distribution enterprises is getting tougher in the SSM market. Therefore, researches on marketing strategies of small and medium-sized supermarkets and distribution enterprises against large-scale discount stores' entering SSM market should be studied further.

Therefore, this paper is intended to analyze how customers' satisfaction and revisit intention are influenced by the service quality of SSM, and to suggest some multi-angle marketing strategies for SSM's competitiveness.

\subsection{Purpose and methods of study}

The purpose of this study is to empirically analyze how service quality and product factors affect customer satisfaction and how customer satisfaction after visiting SSM is related to revisit intention, and to suggest some strategies for SSM to improve service and product factors. For method, a wide range of liter- 
ature reviews including newspapers and national reports were used to make survey questionnaires. Eight hypotheses were built and tested using factor analysis, correlation analysis, and regression analysis.

\section{Literature Review}

\subsection{Super-supermarket}

\subsubsection{Definition}

Super-supermarkets (SSM) are defined as retail stores of $990-3300 \mathrm{~m}^{2}$ scale and they are typically smaller than large-scale discount stores and bigger than supermarkets. Currently, GS Supermarket, Lotte Supermarket, E-mart Everyday, and Homeplus Express are the key players in the SSM market. Domestic large-scale discount stores or department stores enter SSM market when they face limits in finding large-scale site in densely populated area or in expanding in already saturated market. They also have drawn big debates in Korea due to the government regulations recently (Yang et al., 2013).

In the industry, SSM is regarded as a supermarket with over 100 employees operated by major conglomerates. The number of distribution enterprises entering SSM market has increased a lot because they can get significant synergetic advantages when operating large-scale discount stores and SSM at the same time as well as it was their alternative expanding direction out of the saturated market. SSM is a kind of intermediate form between large-scale discount store and supermarket, and regarded as a new concept supermarket with parking capacity of 30-150 vehicles simultaneously in the area of $990-3300 \mathrm{~m}^{2}$. Since last year, GS Retail, Lotte Shopping, and Samsung Tesco have been expanding their SSM stores, acquiring small and medium-sized supermarkets in local areas.

The reason that large distribution enterprises enter SSM market is because it is easier to open a SSM compared with large-scale discount stores which require a large parking lot and a huge site.

\subsection{Service factors}

\subsubsection{Definition of service}

Researches regarding service factors started in early 1960s, comparing service concept with product concept. Recently, the distinction between service and product is gradually getting vague, and especially service is so important today that we can't distinguish service from product indisputably.

In 1960, American Marketing Association (AMA) defined service as "activities, benefits or satisfactions which are offered for sale, or are provided in connection with the sale of goods". Blois (1974) defined service as "an activity offered for sale which yields benefits and satisfactions without leading to a physical change in the form of a good". Also, Stanton (1981) defined service as "separately identifiable, intangible activities which provide want satisfaction when marketed to consumers and/or industrial users and which are not necessarily tied to the sale of a product or another service". Kotler (1973) said that "service is any activity or benefit that one party can offer to another that is essentially intangible and does not result in the ownership of anything".

Many researchers defined service of their own, however, most of them focused on exchange concept of service in the market and they mentioned little about the core concept of service. Also, they usually had taken the perspective of companies. Therefore, a newly structured definition of service is built with the combination of existing definitions, and is reestablished into "service is any activity or benefit that one party can offer to another for satisfaction and benefits, which is intangible and not owned by anything".

In this study, as we discuss the service factors of retailers, service is defined a little bit differently as "the whole process that producers add efforts, time, ideas, and skills to the tangible or intangible products to provide customers with satisfaction and benefits".

\subsubsection{Attributes of service}

The attributes of service can be divided into four categories, intangibility, inseparability of production and consumption, heterogeneity, and perishability.

First, intangibility is the fundamental attribute of service that distinguishes itself from products. Service is a deed, a performance, or an effort, not an object, a device, or a thing that is seen, heard, touched, or smelled. Bateson (1979) claimed that intangibility is the crucial attribute that makes service different from product, and that service includes many tangible actions or facilities but the performance of service is fundamentally intangible. Also he argued that this attribute of service makes it difficult to analyze customers' need and to control service process.

Second, inseparability of production and consumption describes that compared with product which is produced first, then sold, and consumed later, but service is sold first, then produced and consumed almost simultaneously. Performing service consists of physical facilities and psychological and physical labors. This inseparability makes customers involved in production process, and for producers, human resources become critical as a part of service quality.

Third, heterogeneity is related to the potential for change in service quality and performance. The quality of service differs a lot depending on by whom, when, where it is produced. Especially, in highly labor-intensive service sectors, the standard for service performance can be evaluated diversely.

Fourth, perishability describes a service attribute which cannot be stored. Service cannot be stacked and stored as stocks to meet the flexible demands. Therefore, when supply doesn't meet demand, there arise many problems in controlling demand and supply program in service sectors. 


\subsection{Service factors of large-scale discount stores}

Customers select the best store based upon their evaluation criteria set from their personal experiences, information, perceptions, and images. But not all the customers go through this process before selecting a store, and when past experiences or images of a certain store were satisfied, customers revisit the store without specific information process.

Customer service is an importance factor that enhances reliability to the store. Many distribution enterprises provide various services to draw more customers to their stores. Customers evaluate the level of service based on their own expectation of the standard and perceived experience, therefore, understanding customers' expectation about service quality is critical.

Many distribution enterprises attract customers to their stores, providing various forms of services. The services are usually credit sales such as credit card pay, monthly installment pay, or ticket pay, and also include installation and delivery of products, after-sales service, refund and exchange, product guarantee, facilities, cultural events, and complaint handling. These services are offered selectively depending upon different customer attributes and product categories. Today, high value-added services become more and more important as customers' income level has increased and they want value realization rather than just simple after-sales service.

These customer services influence directly to customers' store selection with how they felt about the services after purchasing or visiting the stores.

Walters (1974) categorized distribution enterprises' service types as follows. First, it is service that is intended to increase customers'product satisfaction. It includes consumer finance, sale on credit, and shopping information. Second, it is service that is intended to increase customers'convenience and benefits. It includes delivery, telephone order, and parking facilities. Third, it is service that is intended to offer special benefits to customers. It includes exchange, return, refund, after-sales service, and complaint handling. Especially, Walters specified that return and exchange services influence significantly to customers' store selecting decision.

Customer services become important factors that can increase reliability toward certain store. Thus, distribution enterprises, particularly large-scale discount stores which have grown rapidly around the globe offer various types of services to attract more customers to their stores.

As customers evaluate perceived service level with their standard and expectation of service, it becomes very critical to understand customers' expectation level regarding service standards.

This paper dives into the service factors which are offered to customers by large-scale discount stores that have grown rapidly in Korea recently.

\subsubsection{Product diversity}

Product diversity of certain stores exerts considerable influen- ces on attracting customers. Therefore, the width and depth of product lines are important part of large-scale discount stores' marketing strategy. Customers show higher preference for stores which have assorts of various product lines, brands, and styles than those which do not. When customers don't find specific product that they want to buy in a certain store for a temporary reason, they are likely to turn to evoke negative images toward the store and their store loyalty decreases. For instance, in those situations, a customer generally would try to buy the specific product by visiting another store, delaying purchase, or revisiting the same store later. However, some customers sometimes give up buying the product completely, changing their attitudes and images toward the store.

Therefore, a temporary out of stock may influence directly to customers' decision making for purchase and revisit intention. It leads to decrease of store loyalty also.

\subsubsection{Price of products}

Price is defined as a monetary valuation needed for exchange of products or services. Customers express their right and claim for the product or service as a price level. In other words, price is one of the customers' methods to measure the utility of the product or service.

Price is the top priority factor that customers have in mind when they decide where to purchase. However, depending on the store type, product type, and customer type, reaction to price level is widely spread. Thus, we cannot assure that price is always the top priority. Today, product quality has increased on average and they are so similar one another that it is not easy for customers to evaluate product quality by themselves. Most customers make a judgment of product quality relying on product price level. Price is used not only for store selection but also for quality judgment. When perceived price meets customers' expected price level, purchasing behavior occurs.

Price is a critical factor that lets customers perceive whether a store is favorable or not. Many customers are apt to relate price with product quality. The reasons and cases that customers regard product or service price as an important factor are as follows. First, price is easy to be measured and captured by customers so that customers can trust price as a proxy for quality rather than other factors. Second, customers are likely to believe that certain products or services with higher price would have higher quality than those with lower price level. Third, customers prefer higher-priced products or services to avoid some risks related to quality. Fourth, during customers' store selection process and decision making, they perceive high-priced products consciously rather than low-priced products.

However, perceived price which reflects customers' subjective perception is more critical than real price. The importance of price differs widely depending on variety of customer needs, individualization, and product differentiation, but still it is a crucial factor in store selection process. According to the study of Della, Monroe, and Mcginn is (1981), 10\% discount did not affect much on consumer behavior. 


\subsubsection{Store physical properties}

Store physical properties include escalators, elevators, lightening, toilet structure, location of hallways and width, carpets, parking facilities, rest areas, cafeterias, and shopping districts. Particularly, as these days customers rely heavily on their cars and their lifestyles have changed a lot, parking convenience and rest area facilities have become core factors in determining customers' store perceptions.

\subsubsection{Product quality}

The quality of products that retail stores have is important for customers' reliability. After purchases, the gap between customers'expected product quality and perceived quality influence a lot to store loyalty. These results have been studied in many similar researches such as Prasad (1975), and reliability drawn from product quality should be dealt significantly as a direct factor affecting store selection decision.

\subsubsection{Store location}

Geographic location of stores also can influence on customer satisfaction and store selection behavior.

With all other things being equal, customers are likely to select a store that is close to their residence since they want to purchase a product with least effort. Therefore, the closer a store is, the higher the possibility that a customer would visit the store is, and vice versa.

The effect of store location differs depending on the category of products, for example, when customers purchase low-involvement products such as commodities and groceries, they prefer close stores. On the other hand, for high-involvement products and monopoly products, they might travel long distances for shopping.

\subsubsection{Store atmosphere}

Store atmosphere is composed of a store's external and internal environment including lightening, noise, display and arrangement of products, store area, interior, colors, sounds, fragrance, behavior and way of speaking of sales force, elevators, air conditioning system, other customers in store, and crowdedness. Generally, store atmosphere is the first factor that develops customers' image about the store upon visiting and influences whether customers feel favorable about the store or not.

Recent rapid economic development and increase in customers' income level and consciousness level have made store atmosphere a more crucial factor for store selection. Many retail stores have differentiated their stores to meet customers'individualities, coupled with unique atmosphere and emotional marketing designed to affect customers' feelings.

Kotler (1980) argued that store atmosphere can draw customers' purchasing behavior by triggering emotional feelings. Store atmosphere consists of following factors. First, it includes visual dimension such as colors, lightening, store size, and store interior and exterior. Second, it includes auditory dimension such as volume or sound effect of background music in the store. Third, in includes olfactory dimension such as refreshment inside the store and ventilation condition. Fourth, it includes tactile dimension such as softness and temperature inside the store.

According to Kotler (1974), store atmosphere can be interpreted as the quality of shopping environment. In other words, store atmosphere can evoke some kinds of feelings to customers upon entering the store, and the feelings influence customers'desire to stay in that particular store and revisit intention also. When a customer perceived a certain store's image as a negative one, his or her revisit intention was not high.

\subsubsection{Store reputation}

As multinational distribution enterprises' domestic entry has been a full-scale, customers have shown increasing interests toward highly recognized large-scale discount stores. This reveals that to a certain point, store reputation has a positive relation with customer satisfaction. How store reputation influences customer satisfaction is hypothesized and tested in the later section of this paper.

Zimmer and Golden (1988) claimed that store name affects customers' store selection process and favorable and unfavorable perception toward discount store's images exist according to their studies. And many domestic and foreign studies have argues similar results.

\subsubsection{Employee hospitality}

Sales people face customers at close quarters when customers make purchase decisions. Thus, when it comes to establishing favorable or unfavorable perception about a store, the role of sales people is very critical. As most customers want to be served by sales people with kindness and hospitality, sales people should be educated and trained about the product knowledge, attitude, and kindness.

When customers purchase low-involvement products such as commodities, they usually decide on their own, however, when purchasing high-involvement products, customer interaction with sales people increases. Therefore, most studies regarding sales people have dealt with high-involvement products such as insurance, automobiles, and industrial supplies. But empirical results about the effect of sales people during purchase decision making are relatively scarce. The effect of sales people varies depending on customers'purchasing attributes, relationship with customers, customers' condition at the spot, and talents of sales people.

\subsection{Customers' decision-making process}

When deciding product or service purchase, most customers choose or patronize certain stores which can justify customers' selection criteria. Customers select the most appropriate store 
based on their selection criteria as a composition of their experience, information, perceptions, and images about the store attributes. But not all the customers go through this process before store selection, and they revisit the store without going through this information processing when their past experience and images were all satisfying.

In other words, customers'store selection and patronage are the results of store image formation with the help of experience, information, perceptions, and attitudes. They choose a store when their evaluation based on their selection criteria is positive, and they don't when their evaluation is negative. In other words, their choice of a certain store means their reliability about the store's attributes. When the evaluation result is negative to the unreliable point, they give up the store and look for another alternative positively.

According to the study of Engel, Blackwell, and Miniard (1995), customers'store selection process involves comparison of perceived characteristics of stores with their evaluative criteria and as a result, they distinguish acceptable stores from unacceptable stores. Critical factors in the store selection process are the customers' expectation about the store and perceived experiences.

Monroe and Guiltinan (1975) argued that customers possess store selection evaluative criteria in their minds and they compare those criteria with experience to decide where to visit. Especially, when purchasing high-involvement products, they do extended decision making, however, with low-involvement products, they do routinized decision making. Also the authors claimed that to understand the customer store selection and patronage behavior, we should inquire into the demographic characteristics, life styles, individuality, and economic variables of customers. This is because the store image is regarded to be determined through customer characteristics and marketing strategies of retail stores. When customers' perceived store image is similar to the customers'needs that they seek, the store image turns to be favorable and the likelihood of revisit increases. Also, upon visiting the store, if customers are satisfied with the store atmosphere and reinforce favorable images, revisit intention becomes much higher. As a result, store loyalty is inspired and retained.

According to the study of Spiggle and Sewall (1987), store selection and customer patronage are formed as a result of processing information about customers' perceptions, images, and attitude toward the store based on the customer needs. This also implies that customers' decision making is done by comparing perceived store characteristics with customers' evaluative criteria. Customers purchase in the finally selected store after going through comparison and evaluation process of store attributes and images.

To comprehensively analyze the literatures, influence factors to store selection are divided broadly into customer/purchasing attributes and store attributes. Customer demographic characteristics, life styles, and individuality affect general behavior of purchasing and information search, and customers weigh the im- portance of various store attributes differently depending on their characteristics and individuality. The differently weighted store attributes are then evaluated and influence customers'store selection decision making, and further to product or brand choice. Therefore, customers' store selection can be understood as a result of a combination and interaction of customer characteristics and store attributes.

Customer characteristics can be developed with customers' self-improvement, however, store attributes should be developed by marketing strategies of distribution enterprises. And the store revisit intention and patronage are established upon the considerable effect of interaction between customer characteristics and store attributes.

\section{Model and Hypotheses}

\subsection{Model}

This paper examines the effect of customer satisfaction on store selection and revisit intention, regarding SSM's service factors. It is intended to help to formulate SSM's marketing strategies and to provide suggestions to enhance customer satisfaction.

The research model of this empirical study is depicted in the $<$ Figure $1>$.

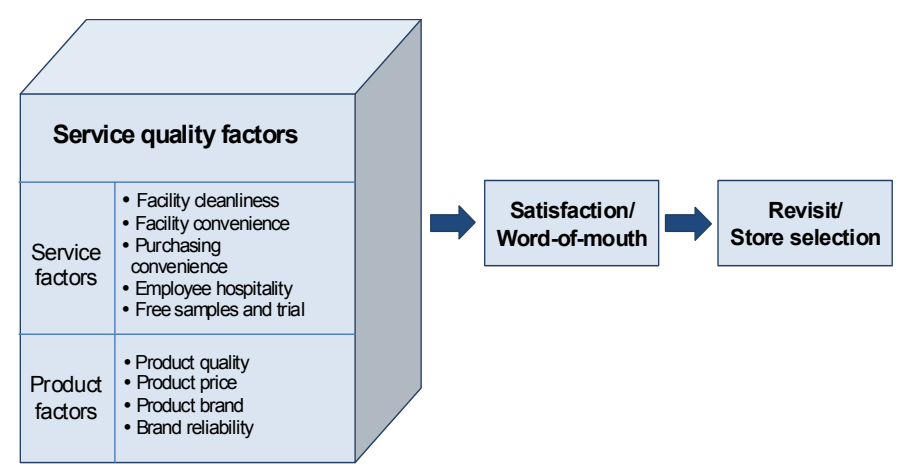

$<$ Figure 1> Research model

\subsection{Hypotheses}

I posit several hypotheses in this paper to look into the relationship between SSM service factors and customer satisfaction, and further, to find which factors critically influence customers' SSM selection.

H1. For customers visiting SSM, service factors will have a positive relationship with customer satisfaction.

H2. For customers visiting SSM, product factors will have a positive relationship with customer satisfaction.

H3. For customers visiting SSM, service factors will have a positive relationship with word-of-mouth effect. 
H4. For customers visiting SSM, product factors will have a positive relationship with word-of-mouth effect.

H5. For customers visiting SSM, service factors will have a positive relationship with revisit intention.

H6. For customers visiting SSM, product factors will have a positive relationship with revisit intention.

H7. For customers visiting SSM, customer satisfaction will have a positive relationship with word-of-mouth effect.

H8. For customers visiting SSM, word-of-mouth will have a positive relationship with revisit intention.

\section{Methodology}

Survey method was used and 127 respondents responded. Respondents were carefully selected SSM customers varying in their gender, age, and income level. Surveys were done in the Jeonnam and Gwangju area.

\subsection{Descriptive statistics}

Descriptive statistics analysis is implemented to understand the characteristics of variables and to find implications for more detailed statistical analysis.

For measuring the variables, 5-point Likert scale was used. The result of descriptive statistics about five variables is as shown in the <Table 1>. To compare the mean values, all variables ranged from 3 to 4 . And all variables have standard deviation value less than 1 , which means that the samples were not scattered much. Also, skewness represents how much the data is skewed toward left or right side from the mean, and we usually use Pearson's coefficient to measure it. When the data has bilateral symmetry, the coefficient value is similar to zero. Positively skewed distribution shows tail shape on the right, and negatively skewed distribution shows tail shape on the left. In this study, distribution of customer satisfaction and word-of-mouth effect are negatively skewed, and that of repurchase intention, product factors, and service factors are positively skewed. Kurtosis is used to describe the distribution of observed data around the mean. When the value is zero, it is normal distribution. With positive value of kurtosis, the graph is more densely populated than normal distribution so that it looks more pointed and sharp, and with negative value of kurtosis, the graph looks flatter than normal distribution. In this study, distribution of customer satisfaction, word-of-mouth effect, and service factors looks pointed but that of repurchase intention and product factors looks flatter and widely spread.

\subsection{Factor analysis}

Validity is the extent to which a concept or measurement is well-founded and correspond accurately to what is intended to be measured. It is considered to be the degree to which the statistical tool measures what it claims to measure. In this study, factor analysis was used to verify internal validity. The purpose of factor analysis is to group highly correlated items into one factor while keeping mutual independence among the factors. Thus, each factor has different meaning, and items inside the same factor have convergent validity. Discriminant validity is sustained among different factors. Varimax method was used for factor rotation, and the result is described in $<$ Table 2>. When conducting principal component analysis, factor loading value should be examined as it explains correlation between factors and variables. If the factor loading is higher than 0.5 , the value is regarded to be statistically significant.

Eigen-value measures the amount of the variation explained by each principal component. An Eigen-value greater than 1 indicates that principal components account for more variance than accounted by one of the original variables in standardized data. In the <Table 2>, as all factor loading values are higher than 0.5 with Eigen-values greater than 1, this indicates that all variables are valid to explain each factor.

In this paper, service factors and product factors are grouped as a result of factor analysis, and the Eigen-value for service factors was 4.136 while that for product factors was 1.579 Explanatory variance was 45.954 for service factors and 17.542 for product factors.

$<$ Table 1> Descriptive statistics result

\begin{tabular}{|c|c|c|c|c|c|c|c|c|c|}
\hline Variable & Range & Minimum & Maximum & Mean & $\begin{array}{c}\text { Standard } \\
\text { error }\end{array}$ & $\begin{array}{c}\text { Standard } \\
\text { deviation }\end{array}$ & Variance & Skewness & Kurtosis \\
\hline Service factors & 5.93132 & -3.47312 & 2.45820 & .000 & .12126781 & 1.000 & 1.000 & -.564 & 1.873 \\
\hline Product factors & 6.26939 & -3.70484 & 2.56455 & .000 & .12126781 & 1.000 & 1.000 & -.484 & 2.434 \\
\hline $\begin{array}{c}\text { Customer } \\
\text { satisfaction }\end{array}$ & 3 & 2 & 5 & 3.49 & .093 & .763 & .582 & -.053 & -.289 \\
\hline $\begin{array}{c}\text { Word-of-mouth } \\
\text { effect }\end{array}$ & 4 & 1 & 5 & 3.38 & .111 & .915 & .837 & -.243 & -.390 \\
\hline Revisit intention & 4 & 1 & 5 & 3.68 & .099 & .818 & .670 & -.509 & .775 \\
\hline
\end{tabular}


$<$ Table 2> Factor analysis result

\begin{tabular}{|c|c|c|c|}
\hline \multirow{3}{*}{ Components } & Survey questionnaire & \multicolumn{2}{|c|}{ Factor loading } \\
\cline { 3 - 4 } & & $\begin{array}{c}\text { Service } \\
\text { factor }\end{array}$ & $\begin{array}{c}\text { Product } \\
\text { factor }\end{array}$ \\
\hline \multirow{3}{*}{ SSM service } & Facility cleanliness & .792 & -.032 \\
& Facility convenience & .773 & .221 \\
& Purchasing convenience & .757 & .335 \\
& Employee hospitality & .757 & .378 \\
& Free samples and trials & .749 & .037 \\
\hline \multirow{3}{*}{ SSM product } & Quality & .139 & .837 \\
& Brice & -.045 & .827 \\
& Brand product & .262 & .694 \\
& Eigen-value & .445 & .568 \\
\hline \multicolumn{2}{|c}{ Variance (\%) } & 4.136 & 1.579 \\
& \multicolumn{2}{c}{45.954} & 17.542 \\
\hline
\end{tabular}

\subsection{Reliability analysis}

Reliability of measurement tool means the overall consistency of a measure and the extent to which the tool measures the true value accurately. It is opposed with the concept of measurement error.

When using multi-item scale, we should analyze the reliability and validity of measurement tools to confirm that the items accurately measure what is intended to be captured.

$<$ Table 3> Reliability of variable

\begin{tabular}{|c|cccc|}
\hline Survey questionnaire & Mean & Variance & Correlation & $\begin{array}{c}\text { Cronbach's } \\
\alpha\end{array}$ \\
\hline Facility cleanliness & 38.19 & 33.470 & .457 & .874 \\
Facility convenience & 38.46 & 30.998 & .603 & .866 \\
Purchasing convenience & 38.19 & 31.052 & .699 & .861 \\
Employee hospitality & 38.31 & 30.575 & .725 & .859 \\
Free samples and trials & 38.28 & 33.130 & .498 & .872 \\
Product quality & 38.68 & 31.595 & .613 & .865 \\
Product price & 38.60 & 33.407 & .403 & .877 \\
Product brand & 38.88 & 31.508 & .482 & .875 \\
Brand reliability & 38.60 & 31.736 & .578 & .867 \\
Customer satisfaction & 38.47 & 32.163 & .529 & .870 \\
Word-of-mouth effect & 38.57 & 30.756 & .565 & .869 \\
Repurchase intention & 38.28 & 30.174 & .721 & .858 \\
\hline
\end{tabular}

Statistical reliability represents the internal consistency of measurement, and it is often verified with Cronbach's $\alpha$. Generally a Cronbach's $\alpha$ greater than 0.7 is considered to have high reliability.

As seen from <Table 3>, Cronbach's $\alpha$ for service factors was greater than 0.8 , which is high. Also, 0877 for product price was the highest, and 0.865 for product quality, which is relatively high, too. For this study's dependent variables,
Cronbach's $\alpha$ was $0.870,0.869$, and 0.858 for customer satisfaction, word-of-mouth effect, and repurchase intention, respectively.

\section{Results}

\subsection{Correlation analysis}

Correlation analysis is used to analyze the relatedness of variables measured. In general, correlation value under 0.2 is regarded as negligible, between 0.2 and 0.4 as weak correlation, and over 0.6 as strong correlation. The result of correlation analysis in this study is described in <Table $4>$.

\begin{tabular}{|c|c|c|c|c|c|}
\hline Variable & $\begin{array}{l}\text { Service } \\
\text { factors }\end{array}$ & $\begin{array}{l}\text { Product } \\
\text { factors }\end{array}$ & $\begin{array}{l}\text { Customer } \\
\text { satisfaction }\end{array}$ & $\begin{array}{l}\text { Word-of-mou } \\
\text { th effect }\end{array}$ & $\begin{array}{l}\text { Repurchase } \\
\text { intention }\end{array}$ \\
\hline $\begin{array}{l}\text { Service } \\
\text { factors }\end{array}$ & 1 & & & & \\
\hline $\begin{array}{l}\text { Product } \\
\text { factors }\end{array}$ & .000 & 1 & & & \\
\hline $\begin{array}{l}\text { Customer } \\
\text { satisfaction }\end{array}$ & .190 & $.452^{* * *}$ & 1 & & \\
\hline $\begin{array}{l}\text { Word-of-m } \\
\text { outh effect }\end{array}$ & $.338^{* *}$ & $.315^{\star *}$ & $.607^{\star * *}$ & 1 & \\
\hline $\begin{array}{l}\text { Repurchas } \\
\text { e intention }\end{array}$ & $.537^{\star \star \star}$ & $.340^{\star *}$ & $.566^{\star \star \star}$ & $.726^{\star \star \star}$ & 1 \\
\hline
\end{tabular}

Word-of-mouth effect and repurchase intention had strong positive correlation with service factors at $p<0.05$ and $p<$ 0.001 respectively. Customer satisfaction had positive correlation with product factors at $p<0.001$, while word-of-mouth effect and repurchase intention had significant positive correlation with product factors at $p<0.01$.

\subsection{Hypotheses tests}

Hypothesis 1 and 2 are proposed to test how service and product factors influence customer satisfaction. Multi-regression analysis is used, with SSM customer satisfaction as dependent variable and service and product factors as independent variables.

To test goodness of fit of the regression model, F-test was used. F-value was 10.263, significance probability was 0.000 and statistically significant ( $p<0.001$ ), and adjusted $R^{2}$ was 0.217 . Thus, the regression model has low explanatory power but has statistically high goodness of fit. As a result of multiple-regression, standardized coefficient for "service"factors was 0.452 , with t-value of 4.178 , influencing customer satisfaction the most. However, standardized coefficient for "product" factors was 0.190 , with t-value of 1.753 , and it was not statistically significant as we can see from <Table 5>. Therefore, hypothesis 1 was supported but hypothesis 2 was not supported. 
$<$ Table 5> Multiple-regression result of product and service factors' effect on customer satisfaction

\begin{tabular}{|c|c|c|c|c|c|}
\hline \multirow{2}{*}{ Variable } & \multicolumn{2}{|c|}{$\begin{array}{c}\text { Unstandardized } \\
\text { coefficient }\end{array}$} & \multirow{2}{*}{$\begin{array}{l}\text { Standardized } \\
\text { coefficient } \\
(\beta)\end{array}$} & \multirow{2}{*}{ t-value } & \multirow{2}{*}{$p$-value } \\
\hline & B & $\begin{array}{c}\text { Standard } \\
\text { error }\end{array}$ & & & \\
\hline (Constant) & 3.485 & 0.082 & & 42.569 & 0.000 \\
\hline $\begin{array}{l}\text { Product } \\
\text { factors }\end{array}$ & 0.145 & 0.082 & 0.190 & 1.753 & 0.084 \\
\hline $\begin{array}{l}\text { Service } \\
\text { factors }\end{array}$ & 0.345 & 0.082 & 0.452 & 4.178 & $0.000^{* * \star}$ \\
\hline F-value & & & 10.263 & & \\
\hline P-value & & & $.000^{\star \star *}$ & & \\
\hline Adj- $R^{2}$ & & & .217 & & \\
\hline
\end{tabular}

${ }^{* * *} p<0.001,{ }^{* *} p<0.01,{ }^{*} p<0.05$

Hypothesis 3 and 4 are proposed to test how service and product factors influence word-of-mouth effect. Multi-regression analysis result is described in <Table 6>.

To test goodness of fit of the regression model, F-test was used. F-value was 8.829 , significance probability was 0.000 and statistically significant $\left(p<0.001\right.$ ), and adjusted $R^{2}$ was 0.217 . Thus, the regression model has low explanatory power but has statistically high goodness of fit. As a result of analysis, standardized coefficient for "product" factors was 0.337 , with t-value of 3.071, influencing customers' word-of-mouth effect the most. Also, standardized coefficient for "service" factors was 0.315 , with t-value of 2.868 , and it was statistically significant, having positive relationship. Therefore, hypothesis 3 and 4 were supported.

$<$ Table 6> Multiple-regression result of product and service factors' effect on word-of-mouth

\begin{tabular}{|c|c|c|c|c|c|}
\hline \multirow{2}{*}{ Variable } & \multicolumn{2}{|c|}{$\begin{array}{c}\text { Unstandardized } \\
\text { coefficient }\end{array}$} & \multirow{2}{*}{$\begin{array}{c}\text { Standardized } \\
\text { coefficient } \\
(\beta)\end{array}$} & \multirow{2}{*}{ t-value } & \multirow{2}{*}{$p$-value } \\
\hline & B & $\begin{array}{c}\text { Standard } \\
\text { error }\end{array}$ & & & \\
\hline (Constant) & 3.382 & 0.100 & & 33.868 & 0.000 \\
\hline $\begin{array}{l}\text { Product } \\
\text { factors }\end{array}$ & 0.309 & 0.101 & 0.338 & 3.071 & $0.003^{\star *}$ \\
\hline $\begin{array}{l}\text { Service } \\
\text { factors }\end{array}$ & 0.289 & 0.101 & 0.315 & 2.868 & $0.006^{\star \star}$ \\
\hline F-value & \multicolumn{5}{|c|}{8.829} \\
\hline $\mathrm{P}$-value & \multicolumn{5}{|c|}{$.000^{\star \star *}$} \\
\hline Adj-R² & \multicolumn{5}{|c|}{0.189} \\
\hline
\end{tabular}

${ }^{* * *} p<0.001,{ }^{* *} p<0.01,{ }^{*} p<0.05$

Hypothesis 5 and 6 are proposed to test how service and product factors influence repurchase intention. Multi-regression analysis result is described in $\langle$ Table 7$\rangle$.

To test goodness of fit of the regression model, F-test was used. F-value was 22.063, significance probability was 0.000 and statistically significant $(p<0.001)$, and adjusted $R^{2}$ was 0.386 . Thus, the regression model has statistically high goodness of fit. As a result of analysis, standardized coefficient for "product"factors was 0.537 , with t-value of 5.611 , having positive influence on customers' repurchase intention. Also, standardized coefficient for "service"factors was 0.340 , with t-value of 3.556 , and it was statistically significant $(p<0.01)$, having positive relationship. Therefore, hypothesis 5 and 6 were supported.

<Table 7> Multiple-regression result of product and service factors' effect on repurchase intention

\begin{tabular}{|c|c|c|c|c|c|}
\hline \multirow{2}{*}{ Variable } & \multicolumn{2}{|c|}{$\begin{array}{c}\text { Unstandardized } \\
\text { coefficient }\end{array}$} & \multirow{2}{*}{$\begin{array}{l}\text { Standardized } \\
\text { coefficient } \\
(\beta)\end{array}$} & \multirow{2}{*}{ t-value } & \multirow{2}{*}{$p$-value } \\
\hline & B & $\begin{array}{c}\text { Standard } \\
\text { error }\end{array}$ & & & \\
\hline (Constant) & 3.676 & 0.078 & & 47.273 & 0.000 \\
\hline $\begin{array}{l}\text { Product } \\
\text { factors }\end{array}$ & 0.440 & 0.078 & 0.537 & 5.611 & $\begin{array}{c}0.000^{* \star} \\
*\end{array}$ \\
\hline $\begin{array}{l}\text { Service } \\
\text { factors }\end{array}$ & 0.279 & 0.078 & 0.340 & 3.556 & $0.001^{* *}$ \\
\hline F-value & \multicolumn{5}{|c|}{22.063} \\
\hline P-value & \multicolumn{5}{|c|}{$.000^{\star * *}$} \\
\hline Adj- $R^{2}$ & \multicolumn{5}{|c|}{0.386} \\
\hline
\end{tabular}

${ }^{* * *} p<0.001,{ }^{* *} p<0.01,{ }^{*} p<0.05$

Hypothesis 7 is proposed to test how SSM customer satisfaction influences word-of-mouth effect. Simple-regression analysis result is described in <Table $8>$.

To test goodness of fit of the regression model, F-test was used. F-value was 38.529, significance probability was 0.000 and statistically significant ( $p<0.001$ ), and adjusted $R^{2}$ was 0.359. Thus, the regression model has statistically high goodness of fit. As a result of analysis, standardized coefficient for "customer satisfaction"was 0.607 , with t-value of 6.207 , and it was statistically significant $(p<0.001)$, having positive relationship. Therefore, hypothesis 7 was supported

<Table 8> Simple-regression result of customer satisfaction's effect on word-of-mouth effect

\begin{tabular}{|c|c|c|c|c|c|}
\hline \multirow{2}{*}{ Variable } & \multicolumn{2}{|c|}{$\begin{array}{c}\text { Unstandardized } \\
\text { coefficient }\end{array}$} & \multirow{2}{*}{$\begin{array}{c}\text { Standardized } \\
\text { coefficient } \\
(\beta)\end{array}$} & \multirow{2}{*}{ t-value } & \multirow{2}{*}{$p$-value } \\
\hline & B & $\begin{array}{c}\text { Standard } \\
\text { error }\end{array}$ & & & \\
\hline (Constant) & 0.845 & 0.418 & & 2.020 & 0.047 \\
\hline $\begin{array}{l}\text { Customer } \\
\text { satisfaction }\end{array}$ & 0.728 & 0.117 & 0.607 & 6.207 & $0.000^{\star \star \star}$ \\
\hline F-value & \multicolumn{5}{|c|}{38.529} \\
\hline P-value & \multicolumn{5}{|c|}{$.000^{* * *}$} \\
\hline Adj- $R^{2}$ & \multicolumn{5}{|c|}{0.359} \\
\hline
\end{tabular}

${ }^{* * *} p<0.001,{ }^{* *} p<0.01,{ }^{*} p<0.05$

Hypothesis 8 is proposed to test how SSM customers word-of-mouth effect influences customers' repurchase intention. Simple-regression analysis result is described in <Table 9>.

To test goodness of fit of the regression model, F-test was used. F-value was 73.518 , significance probability was 0.000 and statistically significant ( $p<0.001$ ), and adjusted $R^{2}$ was 0.520 . Thus, the regression model has statistically high goodness of fit. As a result of analysis, standardized coefficient for "word-of-mouth effect" was 0.726 , with $\mathrm{t}$-value of 8.574 , and it was statistically significant $(p<0.001)$, having positive 
relationship. Therefore, hypothesis 8 was supported.

$<$ Table 9> Simple-regression result of word-of-mouth effect to repurchase intention

\begin{tabular}{|c|c|c|c|c|c|}
\hline \multirow{2}{*}{ Variable } & \multicolumn{2}{|c|}{$\begin{array}{c}\text { Unstandardized } \\
\text { coefficient }\end{array}$} & \multirow{2}{*}{$\begin{array}{c}\text { Standardized } \\
\text { coefficient } \\
(\beta)\end{array}$} & \multirow{2}{*}{ t-value } & \multirow{2}{*}{$p$-value } \\
\hline & B & $\begin{array}{l}\text { Standard } \\
\text { error }\end{array}$ & & & \\
\hline (Constant) & 1.480 & 0.265 & & 5.577 & 0.000 \\
\hline $\begin{array}{c}\text { Word-of-mout } \\
\mathrm{h} \text { effect }\end{array}$ & 0.650 & 0.076 & 0.726 & 8.574 & $\begin{array}{c}0.000^{* *} \\
*\end{array}$ \\
\hline F-value & \multicolumn{5}{|c|}{73.518} \\
\hline P-value & \multicolumn{5}{|c|}{$.000^{\star \star \star}$} \\
\hline Adj-R $R^{2}$ & \multicolumn{5}{|c|}{0.520} \\
\hline
\end{tabular}

${ }^{* * *} \mathrm{p}<0.001,{ }^{* *} \mathrm{p}<0.01,{ }^{*} \mathrm{p}<0.05$

\section{Conclusion}

The purpose of this study is to analyze the relationship between SSM's service factors and following customer satisfaction and how satisfaction difference influences customers'repurchase intention. Also it is intended to help marketing managers in SSM to figure out their advantages and disadvantages and to formulate more effective marketing strategies. This study looks into the service factors of SSM and how satisfaction level about each service factor influences SSM selection. From literature reviews, theoretical background was revisited, and hypotheses were proposed followed by empirical analysis. Based on the results of the analysis, it has a contribution in that it can suggest a marketing strategy direction to the reality. Also the survey result of this study is as follows.

SSM customers responded that $44.1 \%$ of them were satisfied with price and $44.1 \%$ were neutral. Regarding the product quality of SSM, $54.4 \%$ were neutral and $33.8 \%$ responded to feel reliable about the quality. Overall, $88.2 \%$ showed positive reaction toward product quality. About product brand reliability, $45.6 \%$ were neutral, $26.5 \%$ were positive, and $22.1 \%$ were negative. The result can be interpreted that the reason of visiting SSM is not because of product brand. $50 \%$ of respondents were satisfied with facility convenience and $36.8 \%$ were neutral. $45.6 \%$ responded that the sales people are kind and $39.7 \%$ were neutral so that the result indicates that the reaction to employee hospitality is positive. Particularly, regarding shopping convenience, $61.8 \%$ were satisfied, $23.5 \%$ were neutral, and $10.3 \%$ were very satisfied. It indicates that customers perceive SSM to be convenient and shopping convenience plays an important role in customers'revisit intention. To combine the results, $42.6 \%$ of all customers responded to be satisfied with using SSM and $41.2 \%$ were neutral. In addition, $33.8 \%$ were neutral, $39.7 \%$ said that they actively spread word-of-mouth, and $8.8 \%$ were very actively spreading word-of-mouth. It is recommended for SSM marketing managers to specifically have an eye on word-of-mouth marketing strategy. In conclusion, this paper gives a suggestion that SSM marketing managers enhance general service quality to satisfy customers and to induce their revisit.

Received: October 08, 2013.

Revised: December 15, 2013.

Accepted: December 15, 2013.

\section{References}

Bateson, J. E. G. (1979). Why We Need Service Marketing. In O. C. Ferrel, S. W. Brown, \& C. W. Lamb, Conceptual and Theoretical Developments in Marketing, (pp.131-146). Chicago, IL: American Marketing Association.

Blois, K. J. (1974). The Marketing of Services: An Approach. European Journal of Marketing, 8(2), 137-145.

Della Bitta, A. J., Monroe, K. B., \& McGinnis, J. M. (1981). Consumer Perceptions of Comparative Price Advertisements. Journal of Marketing Research, 18(4), 416-427.

Engel, James F., \& Roger, D. Blackwell (1981). Consumer Behavior $\left(4^{\text {th }}\right.$ ed.). New York, NY: Dryden Press.

Jung, Chung-Young, \& Choi, Yi-Gyu (2001). Statistical Analysis with SPSSWIN. Seoul, Korea: Muyok Publishing.

Kim, Jin-Sung, \& Kim, Pan-Jin (2003). A Study on the Store Choice and Satisfaction of Consumer's Large Discount Store and Department. Journal of Korean Regional Development, 3(1), 446-449.

Kotler, P. (1974). Atmospheres as a Marketing Tool. Journal of Retailing, 49(4), 48-64.

Kotler, P. (1980). Principles of Marketing. Englewood Cliffs, NJ: Prentice-Hall.

Monroe, K. B., \& Guiltinan, J. P. (1975) A Path-Analytic Exploration of Retail Patronage Influence. Journal of Consumer Research, 2(1), 19-28.

Prasad, V. K.(1975). Socioeconomic Product Risk and Patronage Preferences of Retail Shoppers. Journal of Marketing, 39(3), 42-47.

Spiggle, S., \& Sewall, M. (1987). A Choice Sets Model of Retail Selection. Journal of Marketing, 51(2), 97-111.

Stanton, W. J. (1981). Fundamentals of Marketing. New York, NY: McGraw-Hill.

Walters, G. (1974). Consumer Behavior: Theory and Practice. Irwin, PA: Home Wood.

Yang, Hoe-Chang, Jeon, Jun-Ho, \& Ju, Yoon-Hwang (2013). A Study on the Impact of Perceived Regulations for Sales at Super-Supermarket and Discount Store on Consumers' Shopping Value and Subjective Well-Being. Journal of Distribution Science, 11(11), 83-88.

Zimmer, M. R., \& Golden, L. L.(1988). Impressions of Retail Stores: A Content Analysis of Consumer Images. Journal of Retailing, 64(3), 265-293. 